\title{
Measuring Congressional Partisanship on Energy and the Environment in the Age of Obama: The Cases of Offshore Drilling in Alaska and the Keystone XL Pipeline
}

\section{Robert McMonagle}

Neumann University, Aston, PA, USA

Email:mcmonagr@neumann.edu

How to cite this paper: McMonagle, R. (2016) Measuring Congressional Partisanship on Energy and the Environment in the Age of Obama: The Cases of Offshore Drilling in Alaska and the Keystone XL Pipeline. Open Access Library Journal, 3: e3181. http://dx.doi.org/10.4236/oalib.1103181

Received: October 28, 2016

Accepted: November 25, 2016

Published: November 29, 2016

Copyright $\odot 2016$ by author and Open Access Library Inc.

This work is licensed under the Creative

Commons Attribution International

License (CC BY 4.0).

http://creativecommons.org/licenses/by/4.0/

\section{(c) (i) Open Access}

\begin{abstract}
The hypothesis for this article is that partisan voting in the US Congress since the 1980s prompts the need to confirm it empirically as a baseline for exploring other variables that may influence public policy decisions. It is worthwhile to measure that partisanship in two key energy-environmental policies during the Obama Presidency. First, how did partisan voting affect the decision by Shell to cease offshore exploratory drilling in the Arctic in 2015? Moreover, was partisanship a factor in President Obama's rejection of the Keystone XL pipeline that year? I found the degrees of congressional partisanship to be very high on key votes in both cases, but relatively lower in the Keystone case. The inference is that legislative party politics can offer a partial explanation for policy continuity or change. These findings set the stage for further inquiry on other explanatory variables both within and external to the political system.
\end{abstract}

\section{Subject Areas}

Politics

Keywords

Energy, Environment, Politics, Oil, Obama

\section{Introduction: Research Questions}

This article aims to answer the questions: what role, if any, did partisan voting in the Congress play in terminating Alaskan offshore drilling and the Keystone XL Pipeline in 
2015, two highly partisan, highly symbolic issues? In addition, what does the use of symbols in these contemporary debates over energy and the environment have to do with that partisanship? And, how does the congressional partisanship variable provide a foundation, or reference point for a prospective, multivariate, statistical analysis of contentious energy-environmental policy debates?

\section{Background}

Observers can measure today's partisanship in Washington, DC, especially on the often-contentious debates over energy versus the environment, by calculating the extent of party line voting in the US House and Senate over time. It is widely regarded that roll-call analysis offers a parsimonious explanation for policy change or continuity, providing an intellectual foundation for exploring additional, more complex variables and their impacts (e.g., see Baumgartner and Jones 1993).

Conventional wisdom says that, in the cases of proposals to drill off the North Slope of Alaska and efforts to construct the Keystone XL Pipeline, majorities of Democrats and Republicans voted on opposite sides of these policy issues. Both issues became highly partisan and highly symbolic (e.g., job creation versus oil spills and climate change) and sometimes exaggerated under scrutiny, which created a stalemate and blocked drilling and the pipeline, according to this empirical analysis that had been lacking in the literature. The period covered in this research is 2011-13 during the Obama Administration when both chambers cast key votes, with the GOP controlling the House and the Democrats controlling the Senate (i.e., divided government).

\section{Key Political Science Literature}

Further, symbols may be utilized by policy coalitions and catalyze this partisanship. As McMonagle (2008) indicates, both environmental and energy interests tend to exaggerate their claims (when held up to scrutiny) through using symbols to help define policy issues. Why? They do so in order to maintain a presence on Capitol Hill and to help set political agendas. Further, symbols can cause issues to ebb and flow on or off the agenda just as oil-soaked creatures helped to delay a vote on ANWR drilling after the 1989 Exxon Valdez spill in Alaska (158-159). That spill was a focusing event (see Kingdon) for the ANWR drilling issue onshore debates during the "Bush 41" years, just as the BP oil spill or event made Alaskan offshore drilling a salient issue and partisanship evident. Moreover, a plethora of media accounts about the US economy not producing adequate jobs versus the threat of climate change represents the critical symbols within the Keystone XL Pipeline debates.

In the Alaska case, the geological history of Royal Dutch Shell is an interesting one. It employed resources to search for Alaskan gold nearly a century ago, making the transition to pursue hydrocarbons in Arctic waters during the 1980s. The firm abandoned sixteen exploratory wells at that time as oil prices plummeted, so there is a historical parallel with its decision in 2015 to follow suit in the Arctic. In between, the deadly symbolism of the 1989 Exxon Valdez environmental disaster seemed to dissuade the 
firm from pressing matters as many Alaskans, including Natives, feared for their livelihoods. But the political pendulum shifted back toward drilling by the 2008 Presidential race as chants of "drill baby drill" coalesced around the McCain-Palin GOP ticket as oil priced skyrocketed [1].

James Anderson (1994) and Murray Edelman (1995) are key scholars who have explored the importance of symbols in political behavior. Employing those approaches, McMonagle (2008) posits that the Porcupine Caribou herd and the "small footprint" for drilling metaphor were among the key competing symbols influencing public policy decisions whether to drill onshore at the Arctic National Wildlife Refuge (ANWR); use of these symbols facilitated issue definition and fostered partisan voting in Congress. The same research also uncovered that voting for offshore drilling, particularly in the Gulf of Mexico prior to the BP Gulf oil spill of 2010, gained bipartisan support in the US Congress given the dearth of symbols. Contrast the pre-BP spill and its pro-drilling bipartisanship with its aftermath when National Geographic and other media accounts displayed waterfowl and a host of other creatures (see http://www.nationalgeographic.com/) in the wake of the Gulf spill. This represents a parallel with the 1989 Exxon Valdez event that killed creatures there along with what had been largely bipartisan hearings on Congress favoring opening up the ANWR for hydrocarbon development [2].

\section{The Problem: A Need for Roll-Call Analyses}

Fast forward to April 2010 and the BP Deepwater Horizon disaster, the worst offshore spill in US history, which thwarted Shell's drilling plans in the Gulf that year. Images of dead or dying sea life and birds necessarily thwarted offshore drilling prospects across the US, and partisanship reined in the several years that followed, as we shall see shortly.

Yes, BP continued developing their 10 test wells (and supportive lobbying efforts) in the Beaufort and Chukchi Seas. Just one month prior to the spill, President Obama called for new drilling off the East and Gulf Coasts and in Alaska. Corporate oil interests with stakes in Alaska had a seat at the table even during the BP spill as a board member of Conoco Phillips, former EPA Chief William Reilly, co-chaired the investigation. In addition, Shell received drilling permits from the Obama Administration in 2011 from DOI, the EPA Appeal's Board, and NOAA, coupled with an Obama executive order requiring them to work together [1]. But by mid-2014, the precipitous drop in oil prices, which continued into 2016, likely influenced Shell's decision to pull out of the Arctic offshore race (at least for now) in the face of environmentalists' protests, along with unfulfilled prospects of developing its Burger J well coupled with a rig running aground in 2012 [3].

Meanwhile, on Capitol Hill there have been numerous House and Senate votes taken on offshore drilling over the past decade. Importantly, these votes warrant a roll-call analysis of partisanship to confirm the rhetoric and media accounts that made the issue salient since the BP spill; this will serve as a reference point for exploring other political 
forces. I identified three critical votes on proposals to drill offshore in Alaska (or onshore at ANWR in one instance) [4].

Two roll call votes were taken in the House in 2011 and 2012 under Republican majorities (Roll calls \#94, \#511), and another in the Senate in 2012 under a Democratic majority (Roll call \#38) during the $112^{\text {th }}$ Congress (see Table 1 for party control in Congress transcending both case studies).

Specifically, the GOP-controlled House approved an amendment to block the EPA Environmental Appeals Board from reviewing offshore drilling permits off Alaska. Further, the House voted to replace the Obama offshore drilling plan to, among other things, offer more offshore leasing opportunities near Alaska and in the Arctic Ocean. In the Democratic Senate, the upper chamber rejected a measure to open ANWR for drilling and approve the Keystone XL Pipeline, among other provisions. Importantly, each of these three votes was very partisan, based on a roll-call methodology dating back to Stuart Rice's approach from the 1920s (see Appendix for my roll-call analyses for both the Alaska offshore and Keystone XL cases).

In this first variable, partisan voting in Congress, my research shows that, since the Deepwater Horizon/BP spill of 2010, offshore drilling has taken on symbolic meaning (e.g., dead marine life, water fowl, and threats to tourism and fishing), and has therefore shifted the debate in Congress to a partisan one on offshore drilling. In contrast, before the Gulf of Mexico oil spill, McMonagle (105, 185-186) noted the Senate cast two procedural votes in July 2006 to break cloture and thereby permit an up-or-down vote on offshore drilling. Importantly, the Senate ultimately passed the measure (79-9) in December 2006 and a Democratic-controlled Congress approved drilling at Lease Area 181 in a bipartisan manner in 8.3 million acres in the Eastern Gulf of Mexico.

\section{The Findings}

While 100 percent of the three key votes on Alaskan offshore drilling were very partisan, only 80 percent of the five key votes on the Keystone XL Pipeline proposal were found to be very partisan, 20 percent (or one vote) was only somewhat partisan. Inferentially, partisan-driving symbols were relatively not as identifiable or powerful in the Keystone case (e.g., lost construction jobs).

Table 1. Party composition of the US house and senate for key votes in the Alaska offshore drilling and keystone XL pipeline cases (2011-13).

\begin{tabular}{cccc}
\hline Year & Congress & Majority & Seats \\
\hline \multirow{2}{*}{2011} & $112^{\text {th }}$ & House: Republican & $242-193$ \\
& & Senate: Democrat & $51-47-2$ \\
2012 & \multirow{2}{*}{$112^{\text {th }}$} & House: Republican & $242-193$ \\
& & Senate: Democrat & $51-47-2$ \\
\multirow{2}{*}{2013} & $113^{\text {th }}$ & House: Republican & $234-201$ \\
& & Senate: Democrat & $53-45-2$ \\
\hline
\end{tabular}

Sources: House.gov; Senate.gov. 
In the second case study for this article, and during the $112^{\text {th }}$ Congress, the House cast one vote in 2011 to approve the Keystone XL project, another in 2012, and two Senate votes in 2012. Divided government was the norm as the House was under GOP control, while the Democrats controlled the Senate. All votes were very partisan. The next year, the Senate passed a non-binding measure on a somewhat partisan vote in favor of the Keystone XL Pipeline. Yet, the project also needed Presidential approval, which President Obama declined later in 2015, even with the issue salience of tens of millions of Americans out of the workforce.

The political history of Keystone XL dates back to 2005 when the TransCanada Corporation proposed building a pipeline extending from Alberta, Canada to Illinois, transporting around 400,000 barrels of crude per day at a cost of $\$ 1.7$ billion. While the Canadian Government and US State Department approved that portion of what would become the Keystone XL Pipeline in 2007 and 2008 respectively, President Obama delayed the final American decision on the larger project until after the 2012 Presidential Election. Notwithstanding, House Republicans cast several votes aimed at pressuring the President to finally approve the project. He did not approve it, ultimately, despite the State Department's conclusion that Keystone likely would not change greenhouse gas emissions (that President Obama aimed to reduce). This conclusion noted that, although Canadian oil sands for the pipeline would produce more greenhouse gases, defeating the project would not preclude developing those hydrocarbons [5].

McMonagle (2008) [6] first raised the prospect of a future roll call and multivariate analysis [7] of offshore Alaskan drilling and its implications. This article builds on that proposition, which, may now be especially salient for political scientists in the international relations and comparative politics subfields given media accounts of Russia's renewed economic and military interests in the Arctic region. In addition, given its importance to lawmakers through media accounts, offshore Alaska drilling debates are likely to resurface when oil and gas prices again spike as they always do.

\section{Conclusions}

The partisan voting pattern across these two environmental-energy policy cases suggests that partisan voting in Congress has been a necessary but not necessarily sufficient condition for the policy shift against offshore drilling since the 2010 BP Gulf spill and for policy continuity on votes favoring development of the Keystone XL Pipeline. It would be disingenuous to study the environment or energy matters exclusively. A shortcoming with this research is that a combination of political variables could offer a more complete explanation for the shift against offshore drilling and in favor of the Keystone XL project. Possible factors include the impacts of public opinion, the entry of new actors, or decision makers/institutions into these debates, along with measuring how the media and US Congressional committees defined these projects, as either proenvironment or pro-energy. The key idea is that the more variables in addition to partisan voting in Congress supporting either position, the greater likelihood that they influenced the policy decisions. 
However, what about divided government? Does it matter as much as partisanship? On the one hand, divided government may be a less important influence on policy in the offshore drilling case because there was a bipartisan vote in Congress in 2006 under divided governmental system that supported expanded drilling prior to the BP oil spill of 2010 [8]. On the other hand, the Keystone case (and possibly) AK drilling likely would have passed if Republicans controlled both Congress and the White House more recently.

The contribution of this study is a basic empirical understanding of one of the most contentious and important forces, partisan voting, and its impacts. Of course, the decisions by Shell and President Obama in 2015 ultimately slew (at least for now) Alaskan offshore drilling and the Keystone projects respectively. This research is a critical reference point for additional scholarship exploring the independent variables cited above (besides partisanship) that so often dominate the political discourse in today's America, especially in the environmental-energy arena.

\section{References}

[1] Broder, J. and Krauss, C. (2012) New and Frozen Frontier Awaits Offshore Drilling. New York Times, May 23.

[2] McMonagle, R. (2008) Caribou and Conoco: Rethinking Environmental Politics in Alaska's ANWR and beyond. Lexington Books, Lanham, MD, 207-208.

[3] Smith, G. (2015) Shell Abandons Arctic Drilling After Poor Test Results. http://fortune.com/2015/09/28/shell-abandons-arctic-drilling-after-poor-test-results/

[4] Dirty Energy Money. http://dirtyenergymoney.org/votes

[5] Eilperin, J. and Mufson, S. (2014) State Department Releases Keystone XL Final Environmental Impact Statement. The Washington Post, January 31.

https://www.washingtonpost.com/business/economy/state-to-release-keystones-final-environme ntal-impact-statement-friday/2014/01/31/3a9bb25c-8a83-11e3-a5bd-844629433ba3_story.html

[6] McMonagle, R. (2008) Caribou and Conoco: Rethinking Environmental Politics in Alaska's ANWR and beyond. Lexington Books, Lanham, MD, 165.

[7] Baumgartner, F. and Jones, B. (1993) Agendas and Instability in American Politics. The University of Chicago Press, Chicago.

[8] McMonagle, R. (2008) Caribou and Conoco: Rethinking Environmental Politics in Alaska's ANWR and beyond. Lexington Books, Lanham, MD, 105.

\section{List of Acronyms}

ANWR: Arctic National Wildlife Refuge

DOI: US Department of the Interior

EPA: US Environmental Protection Agency

NOAA: National Oceanic and Atmospheric Administration 


\section{Appendix}

Roll Call Votes and Rice Index Measurements in the Alaska Offshore Drilling Case in 2011-12 (see McMonagle 97 for Rice Index Value cutoff points (40) on degrees of partisanship):

House Roll Call \#94 (2/18/11): The House voted on an amendment offered by Congressman Don Young, R-AK (243-185; D13-176; R230-9) to block the EPA Environmental Appeals Board from reviewing offshore drilling permits off Alaska. Rice Index Values (D86.2; R92.4) make this a VERY PARTISAN VOTE.

Rice Index Value Calculation:

Democrats 189

(13 aye $/ 189 \times 100=6.9 \%$ in favor)

$(176$ nay $/ 189 \times 100=93.1 \%$ opposed $)$

Rice Index Value $\quad(93.1-6.9=86.2)$

Republicans $239 \quad(230$ aye $/ 239 \times 100=96.2 \%$ in favor $)$

$(9$ nay $/ 239 \times 100=3.8 \%$ opposed $)$

Rice Index Value $\quad(96.2-3.8=92.4)$

House Roll Call \#511 (7/25/12): The House voted (253-170; D25-161; R228-9) to replace the Obama offshore drilling plan to, among other things, offer more offshore leasing opportunities near Alaska and in the Arctic Ocean. Rice Index Values (D73.2; R92.4) make this a VERY PARTISAN VOTE.

Rice Index Value Calculation:

Democrats $186 \quad(25$ aye $/ 186 \times 100=13.4 \%$ in favor $)$ $(161$ nay $/ 186 \times 100=86.6 \%$ opposed $)$

Rice Index Value $\quad(86.6-13.4=73.2)$

Republicans $237 \quad(228$ aye $/ 237 \times 100=96.2 \%$ in favor $)$ $(9$ nay $/ 237 \times 100=3.8 \%$ in favor $)$

Rice Index Value $\quad(96.2-3.8=92.4)$

Senate Roll Call \#38 (3/13/12): The Senate rejected an amendment requiring a $3 / 5$ supermajority (41-57; D2-50; R38-7) to open ANWR for drilling and approve the Keystone XL Pipeline, among other provisions. Rice Index Values (D92.4; R68.8) make this a VERY PARTISAN VOTE.

Rice Index Value Calculation:

Democrats $52 \quad(2$ aye $/ 52 \times 100=3.8 \%$ in favor $)$

(50 nay $/ 52 \times 100=96.2 \%$ opposed $)$

Rice Index Value $\quad(96.2-3.8=92.4)$

Republicans $45 \quad(38$ aye $/ 45 \times 100=84.4 \%$ in favor $)$

$(7$ nay $/ 45 \times 100=15.6 \%$ opposed $)$

Rice Index Value $\quad(84.4-15.6=68.8)$

Roll Call Votes and Rice Index Measurements in the Keystone XL Pipeline Case in 2011-13: 
House Roll Call \#650 (7/26/11): The House voted (279-147; D47-144; R232-3) to direct the President to speed approval of the Keystone XL Pipeline by passing the North American-Made Energy Security Act. Rice Index Values (D50.8; R97.4) make this a VERY PARTISAN VOTE.

Rice Index Value Calculation:

Democrats $191 \quad(47$ aye $/ 191 \times 100=24.6 \%$ in favor $)$

$(144$ nay $/ 191 \times 100=75.4 \%$ opposed $)$

Rice Index Value $\quad(75.4-24.6=50.8)$

Republicans $239 \quad(232$ aye $/ 235 \times 100=98.7 \%$ in favor $)$

( 3 nay $/ 235 \times 100=1.3 \%$ opposed $)$

Rice Index Value $\quad(98.7-1.3=97.4)$

House Roll Call \#292 (5/18/12): This non-binding House vote (261-152; D26-151; R235-1) would instruct conferees to approve the Keystone XL Pipeline as part of a 2012 transportation reauthorization bill. Rice Index Values (D70.6; R99.2) make this a VERY PARTISAN VOTE.

Rice Index Value Calculation:

Democrats $177 \quad(26$ aye $/ 177 \times 100=14.7 \%$ in favor $)$

$(151$ nay $/ 177 \times 100=85.3 \%$ opposed $)$

Rice Index Value $\quad(85.3-14.7=70.6)$

Republicans $236 \quad(235$ aye $/ 236 \times 100=99.6 \%$ in favor $)$

( 1 nay $/ 236 \times 100=0.4 \%$ in favor)

Rice Index Value $\quad(99.6-0.4=99.2)$

Senate Roll Call \#34 (3/8/12): The Senate vote on an amendment to S. 1813 fell short of the $3 / 5$ supermajority needed (56-42; D11-40; R45-0) to approve the Keystone XL pipeline project with accompanying environmental protection and government oversight. Rice Index Values (D56.8; R100) make this a VERY PARTISAN VOTE.

Rice Index Value Calculation:

Democrats $51 \quad(11$ aye $/ 51 \times 100=21.6 \%$ in favor $)$

$(40$ nay $/ 51 \times 100=78.4 \%$ opposed $)$

Rice Index Value $\quad(78.4-21.6=56.8)$

Republicans $45 \quad(45$ aye $/ 45 \times 100=100 \%$ in favor $)$

( 9 nay $/ 45 \times 100=0 \%$ in favor)

Rice Index Value $\quad(100-0=100)$

Senate Roll Call \#38 (3/13/12): The Senate rejected an amendment requiring a $3 / 5$ supermajority (41-57; D2-50; R38-7) to open ANWR for drilling and approve the Keystone XL Pipeline, among other provisions. Rice Index Values (D92.4; R68.8) make this a VERY PARTISAN VOTE.

Rice Index Value Calculation:

Democrats $52 \quad(2$ aye $/ 52 \times 100=3.8 \%$ in favor $)$ 
Rice Index Value

(50 nay $/ 52 \times 100=96.2 \%$ opposed $)$

$(96.2-3.8=92.4)$

Rice Index Value $\quad(84.4-15.6=68.8)$

Senate Roll Call \#61 (3/22/13): This non-binding Senate vote requiring a simple majority (62-37; D17-35; R45-0) would "establish a deficit-neutral reserve fund to promote investment and job growth in United States manufacturing, oil and gas production, and refining sectors through the construction of the Keystone XL Pipeline." Its critics asserted it would circumvent the normal presidential permit process. Rice Index Values (D34.6; R100) make this a SOMEWHAT PARTISAN VOTE.

Rice Index Value Calculation:

$\begin{array}{ll}\text { Democrats } 52 & (17 \text { aye } / 52 \times 100=32.7 \% \text { in favor }) \\ & (35 \text { nay } / 52 \times 100=67.3 \% \text { opposed }) \\ \text { Rice Index Value } & (67.3-32.7=34.6) \\ \text { Republicans } 45 & (45 \text { aye } / 45 \times 100=100 \% \text { in favor }) \\ & (0 \text { nay } / 45 \times 100=0 \% \text { in favor })\end{array}$

Rice Index Value $\quad(100-0=100)$

Submit or recommend next manuscript to OALib Journal and we will provide best service for you:

- Publication frequency: Monthly

- 9 subject areas of science, technology and medicine

- Fair and rigorous peer-review system

- Fast publication process

- Article promotion in various social networking sites (LinkedIn, Facebook, Twitter, etc.)

- Maximum dissemination of your research work

Submit Your Paper Online: Click Here to Submit

Or Contact service@oalib.com 